NBER WORKING PAPER SERIES

\title{
NON-ECONOMIC ENGAGEMENT AND INTERNATIONAL EXCHANGE: THE CASE OF ENVIRONMENTAL TREATIES
}

\author{
Andrew K. Rose \\ Mark M. Spiegel \\ Working Paper 13988 \\ http://www.nber.org/papers/w13988
NATIONAL BUREAU OF ECONOMIC RESEARCH
1050 Massachusetts Avenue
Cambridge, MA 02138

May 2008

Rose is B.T. Rocca Jr. Professor of International Trade and Economic Analysis and Policy in the Haas School of Business at the University of California, Berkeley, NBER research associate and CEPR research fellow. Spiegel is Vice President, Economic Research, Federal Reserve Bank of San Francisco. Rose thanks INSEAD, the MAS, and NUS for hospitality during the course of this research. For comments, we thank: an insightful anonymous referee, Meredith Crowley, Jonathan Eaton, Raquel Fernandez, Mark Gertler, Kris Mitchener, Masao Ogaki, seminar participants at: FRBNY, NYU, Oregon, and Tokyo, and conference participants at the 2007 AEA and PEIF meetings. Christopher Candelaria provided excellent research assistance. The views expressed below do not represent those of the Federal Reserve Bank of San Francisco, the Board of Governors of the Federal Reserve System, or the National Bureau of Economic Research. Older and current (PDF) versions of this paper, key output and the chief STATA data sets used in the paper are available at http://faculty.haas.berkeley.edu/arose.

NBER working papers are circulated for discussion and comment purposes. They have not been peerreviewed or been subject to the review by the NBER Board of Directors that accompanies official NBER publications.

(C) 2008 by Andrew K. Rose and Mark M. Spiegel. All rights reserved. Short sections of text, not to exceed two paragraphs, may be quoted without explicit permission provided that full credit, including (c) notice, is given to the source. 
Non-Economic Engagement and International Exchange: The Case of Environmental Treaties Andrew K. Rose and Mark M. Spiegel

NBER Working Paper No. 13988

April 2008

JEL No. F10,F34

\begin{abstract}
$\underline{\text { ABSTRACT }}$
We examine the role of non-economic partnerships in promoting international economic exchange. Since far-sighted countries are more willing to join costly international partnerships such as environmental treaties, environmental engagement tends to encourage international lending. Countries with such non-economic partnerships also find it easier to engage in economic exchanges since they face the possibility that debt default might also spill over to hinder their non-economic relationships. We present a theoretical model of these ideas, and then verify their empirical importance using a bilateral cross-section of data on international cross-holdings of assets and environmental treaties. Our results support the notion that international environmental cooperation facilitates economic exchange.
\end{abstract}

Andrew K. Rose

Haas School of Business Administration

University of California

Berkeley, CA 94720-1900

and NBER

arose@ haas.berkeley.edu

Mark M. Spiegel

Federal Reserve Bank of San Francisco

101 Market Street

San Francisco, CA 94105

mark.spiegel@sf.frb.org 


\section{Introduction}

Countries, like people, interact with each other on a number of different dimensions. Some interactions are strictly economic; for instance, countries engage in international trade of goods, services, capital, and labor. But many are not economic, at least not in any narrow sense. For instance, the United States seeks to promote human rights and democracy, deter nuclear proliferation, stop the spread of narcotics, and so forth. Accordingly America, like other countries, participates in a number of international institutions to further its foreign policy objectives; it has joined security alliances like NATO, and international organizations such as the International Atomic Energy Agency. In this paper, we concentrate on the interesting and understudied case of international environmental arrangements (IEAs). We ask whether participation in such non-economic partnerships tends to enhance international economic relations. The answer, in both theory and practice, is positive.

Memberships in IEAs yield costs and benefits. A country can gain directly from such interactions; its air might be cleaner, or there might be more fish in the sea. However, some gains can be indirect. For instance, countries with long horizons and low discount rates might be more willing both to protect the environment and to maintain a reputation as a good credit risk. If they can signal their discount rate through IEA activity, participation in IEAs may indirectly yield gains from improvements in credit terms. Alternatively, countries that are tightly tied into a web of international relationships may find that withdrawing from one domain (such as environmental cooperation), may adversely affect activities in an unrelated area (such as finance). The fear of these spillovers may then encourage good behavior in the first area.

Our theoretical analysis begins with an extension of the "reputation spillover" concept introduced by Cole and Kehoe (1997). In our model, countries - or rather, their policymakers - 
differ in their attractiveness as borrowers. Formally, we model these differences as differing discount rates among borrowing country governments, but one could envision alternative differences, such as disparities across countries in the perceived cost of default on external debt obligations. We concentrate on the example of discount rate differences in our theoretical model for analytical tractability, but we do not intend to suggest that this is the only source of heterogeneity in creditworthiness across countries.

With differing discount rates, more patient governments choose to join a greater number of environmental treaties; this sends a credible signal concerning a country's debt capacity. Creditors respond by lending the country more capital. The predictions of this model are multilateral, since membership in IEAs is easily-accessible common knowledge. A country that joins more IEAs enhances its reputation with all nations.

This multilateral model is an intuitive start. Still, it misses the possibility that membership in an IEA may confer special advantages to its members; if Argentina defaults on its Brazilian debt, Brazil can retaliate by failing to support Argentine environmental initiatives. We thus extend the model to accommodate bilateral spillovers. We allow a creditor to respond to default by reducing the debtor's gains from involvement in mutual IEAs. ${ }^{1}$ This extended model demonstrates that cross-country economic interaction can be a function of solo and/or joint participation in environmental treaties. Succinctly: the more international environmental commitments that countries make individually and in common, the easier is economic exchange between the countries. ${ }^{2}$

We then take these ideas to the data. Using a cross-sectional gravity model to control for other phenomena, we find that participation in IEAs is indeed positively associated with the international exchange of assets. This confirms the notion of positive spillovers between 
environmental cooperation and economic exchange. Moreover, we find that multilateral IEA participation is not a sufficient statistic to explain bilateral economic exchange; joint IEA participation is also related to asset cross-holdings. We corroborate these findings using a panel of data that includes bank loans and FDI. We use a number of instrumental variables to show that our empirical results do not depend on the assumption that causality flows simply from environmental engagement to economic exchange. Our empirics thus support our extended model with both a reputation effect and some sort of bilateral punishment mechanism.

A brief survey of the literature section is provided in section 2, while our theoretical framework is developed in the following section. The empirical work is presented in section 4 . The paper ends with a brief conclusion.

\section{Literature Survey}

The concept of reputation spillovers arose as a response to the Bulow and Rogoff (1989b) challenge to the sovereign debt literature. In their seminal paper, Bulow and Rogoff cast doubt on the possibility of sustainable sovereign lending based solely on the desire of borrowers to maintain their reputations. They demonstrated that such relationships would not be sustainable, because a borrower would eventually prefer to default on its debt and "self-finance" its consumption-smoothing.

This challenge was addressed in a series of papers by Cole and Kehoe (1995, 1997, 1998). They show that the problem with reputation-based borrowing stems from the fact that a borrower able to replicate interactions with other creditors receives only transient benefits from such relationships. At some point, the benefits of maintaining a reputation fall sufficiently that default and subsequent self-finance is the rational response. However, Cole and Kehoe (1995) 
show that the desire to maintain other interactions with creditor nations may support debt, provided that these other relationships are not transient but enduring. Cole and Kehoe (1998) demonstrate that the desire to maintain reputations in enduring relationships can support a debt relationship with transient benefits. Cole and Kehoe (1997) show that the desire to maintain an enduring relationship can support a transient debt relationship in a simple trigger-strategy model, where a creditor responds to default by breaking off debtor relationships with enduring benefits. ${ }^{3}$ We borrow this modeling strategy below in our theoretical work.

Other signals of creditworthiness have also been examined in the literature. Milde and Riley (1988) argue that borrowers can signal the quality of underlying investments through the magnitude of borrowing. Alternatively, borrowers may resume payments subsequent to default, either to affect bargaining negotiations (e.g. Gale and Hellwig, 1989) or to signal government stability (e.g., Cole, Dow, and English, 1995). Similarly, creditworthy borrowers may signal their types by pursuing fiscal contractions (e.g. Drudi and Prati, 2000), enduring costly recessions prior to defaulting, as in Alfaro and Kanczuk (2005), or by accepting rescheduling packages at tough terms as in Spiegel (2005).

On the other hand, default decisions can themselves be signals of other types of information. Sandleris (2006) develops a model where government default decisions provide information about economic fundamentals that affect private sector behavior. He shows that the desire to signal to the domestic private sector that fundamentals are good can be sufficient to generate lending in an environment without default penalties.

A different literature of relevance concerns the formation and characteristics of IEAs; references here include Barrett (1994), Carraro and Siniscalco (1998), and Finus et al (2005). Most of the literature is skeptical about the ability of voluntary self-enforcing IEAs to improve 
on non-cooperative outcomes. The intuition is that the level of any attainable environmental objective - say, abatement of a certain pollutant - is limited in a heterogeneous group by the preferences of the nation least interested in the problem. While there has been some discussion about encouraging greater participation in IEAs through cooperation in other dimensions such as R\&D activity (e.g., Carrero and Siniscalco, 1997), the literature is discouraged by the fact that such agreements are not explicitly found in practice (Barrett, 2003).

Self-enforcing IEAs among proximate countries might be better able to achieve superior outcomes if pollution spillovers are decreasing in distance [e.g. Davies and Naughton (2006)]. However, our analysis abstracts from geographic effects on the benefits of IEAs. ${ }^{4}$

\section{Economic Interaction and Participation in IEAs}

Pure reputation model

We begin with a reputation-based model, where a government's decision to engage in IEAs enhances the ability of private entrepreneurs to acquire portfolio investment from abroad, since it credibly signals a lower discount rate.

We model our analysis in terms of a representative host country. We assume that each host country is endowed with $x$ units of a perishable good in each period, $t=0,1, \ldots, \infty$. There are $K$ foreign countries in the model. We assume that there are a large number of atomistic foreign investors in a representative foreign country $k$ that are willing to extend credit to the host country firms, so long as the expected rate of return is greater than or equal to the risk free rate. ${ }^{5}$ For simplicity, all bonds are assumed to be one-period, and are in the form of portfolio investments that are extended in period $t-1$ and come due in period $t$. As borrowers in the host country are limited to a credit ceiling that precludes default in equilibrium, competition among 
investors from country $k$ ensures that the nominal rate of return is equal to the risk free rate, which we designate as $r^{*}$.

Let $\omega_{t}^{k}$ represent the flow of capital from investors in country $k$ to the host country in period $t$. We assume that there are a large number of atomistic entrepreneurs in the host country who are endowed with a technology that combines the foreign capital from country $k$ to produce aggregate output equal to $y^{k}\left(\omega_{t}^{k}\right)$, where $y^{\prime}>r^{*}$ and $y^{\prime \prime} \leq 0$. For notational simplicity, we drop the $k$ superscripts and work in terms of a representative source country.

A national government maximizes its citizens' discounted utility, subject to the government's discount rate, $\beta$. Utility satisfies

$$
U_{t}=\sum_{i=t}^{\infty} \beta^{i} c_{t}
$$

A continuum of categories of environmental issues $J$ is distributed on the interval $[0, \bar{J}]$ with each category covered by an IEA with density $f(j)$, which we refer to interchangeably as a "treaty." A treaty requires participants to contribute a fixed amount of their consumption good $e$ in each period (including period 0 ) towards improving the environment. IEA $j$ then yields a benefit, $v_{j}$, in each of the following periods $t>0$. We number the treaties such that $v_{j} \geq v_{j+1}$ and assume that $v_{j}$ is a continuous twice-differentiable function of $j$ that satisfies $v_{j}{ }^{\prime}<0, v_{j}{ }^{\prime \prime}>0$, and $\lim _{j \rightarrow \infty} v_{j}=0$. We assume that a treaty is void when one of the signatories shirks, and that the shirker suffers a fixed penalty of $\phi$ each following period.

Private international investments are subject to sovereign risk. We assume that the sovereign makes a repayment decision concerning whether or not to service the nation's outstanding private debt requirements and the private debtors in the borrowing nation comply 
with the sovereign's decision. Default is selective, in that the sovereign makes its default decision on debt obligations to each nation separately. ${ }^{6,7}$

The timing of the model is as follows. In period 0 , the government receives its endowment, and then chooses $j^{*}$, the number of IEAs to join. It then chooses whether or not to comply with the terms of these treaties and spends $e$ if it complies. Next, investors in each country $k$ choose $\omega_{t}$, the aggregate amount of credit to extend to private borrowers in the host country. Finally production occurs, followed by agents in the host country consuming the unused portion of their endowment.

In subsequent periods, the government again decides whether to comply (or not) with the treaty. In addition, it decides whether or not to announce a general default, and the foreign investors choose the amount of new credit to extend to host country borrowers. Finally, agents in the host country produce and consume, subject to any penalties for default or shirking on their environmental commitments.

To insure sub-game perfection, we solve the model backwards, beginning in a representative period $t \geq 1$. Initially, we treat default and IEA penalties as separate; below, we also consider an extension which allows punishment through environmental treaties.

Consumption by country $i$ in period $t>0$ is equal to the country's endowment, plus the net gains from production (the value of output minus debt service) and environmental improvement, minus any penalties incurred for debt default or shirking on IEA commitments: ${ }^{8}$

$$
\left(c_{t} \mid t>0\right)=x+\sum_{i=1}^{K}\left[y\left(\omega_{t}\right)-\tilde{d}_{t}\right]+\int_{0}^{j^{*}} \tilde{v}_{j} f(j) d j
$$


where: $\tilde{v}_{j}$ represents the net payoff from participation in treaty $j$ (which equals $v_{j}-e$ under compliance, and $-\phi$ under non-compliance), and $\tilde{d}_{t}$ represents the individual firm's debt service payment, which equals $\omega_{t} r^{*}$ under debt service, and 0 under default. ${ }^{9}$

Given debt service, the representative country continues to obtain funds from all $k$ countries in each period in the future. Discounted utility under compliance with both signed treaties and debt obligations satisfies:

$$
U_{t}=\left(\frac{1}{1-\beta}\right)\left\{x+\sum_{i=1}^{K}[y(\omega)-\omega r *]+\int_{0}^{j^{*}}\left(v_{j}-e\right) f(j) d j\right\} .
$$

We first examine the choice of how many IEAs to join. Under compliance, the host country gives effort in every period (spends $e$ ), beginning with period 0 , and receives $v_{j}$ in every period beginning with period 1 . Discounted utility in period 0 from joining and complying with debt and treaty obligations satisfies

$$
U_{0}=x+\left(\frac{\beta}{1-\beta}\right)\left\{x+\sum_{i=1}^{K}\left[y(\omega)-\omega r^{*}\right]\right\}+\left(\frac{1}{1-\beta}\right) \int_{0}^{j *}\left(\beta v_{i}-e\right) f(j) d j .
$$

Maximizing $U_{0}$ with respect to $j^{*}$, the host country chooses $j^{*}$ such that

$$
v_{j^{*}}=\frac{e}{\beta} .
$$

The discounted utility from violating the marginal treaty in some future period $t>0$ satisfies

$$
\widehat{U}_{t}=\int_{j^{*}-1}^{j^{*}}\left(v_{j}-\frac{\beta \phi}{1-\beta}\right) f(j) d j+\left(\frac{1}{1-\beta}\right)\left\{x+\sum_{i=1}^{K}\left[y(\omega)-\omega r^{*}\right]+\int_{0}^{j^{*}-1}\left(v_{j}-e\right) f(j) d j\right\} \cdot(6)
$$

By (3) and (6) 


$$
U_{t}-\widehat{U}_{t}=\left(\frac{1}{1-\beta}\right) \int_{j^{*}-1}^{j^{*}}\left[-e+\beta\left(v_{j}+\phi\right)\right] f(j) d j>0
$$

when (5) is satisfied. It follows that the debtor will choose ex post to comply with treaties that are voluntarily signed.

We next turn to the default decision. The marginal decision is whether or not to default on credit obligations to any single country $k$. In the event of such a default, we assume that it loses access private capital flows from that country in the future. Discounted utility subsequent to default on credit obligations to country $k$ satisfies

$$
\widehat{U}_{t}=y(\omega)+\left(\frac{1}{1-\beta}\right)\left\{\left(x+\sum_{m=1}^{K}\left[y(\omega)-\omega r^{*}\right] \mid m \neq k\right)+\int_{0}^{j^{*}}\left(v_{j}-e\right) f(j) d j\right\} .
$$

By (3) and (8), the representative country will choose to default unless

$$
\beta y(\omega)-\omega r^{*} \geq 0
$$

where an interior solution requires the parameter restriction $\beta y^{\prime}-r^{*}<0$, which we adopt.

Substituting (5) into (9) and totally differentiating with respect to $j^{*}$ and $\omega$ yields

$$
\frac{d \omega}{d j^{*}}=\frac{\partial v_{j^{*}}}{\partial j^{*}} \frac{e y(\omega)}{v_{j^{*}}\left(e y^{\prime}-r^{*} v_{j^{*}}\right)} \geq 0
$$

since the denominator will be negative in the range where entrepreneurs in the host country are credit constrained.

Equation (10) indicates that the credit ceiling will be a function of the creditor's perception of the discount rate of the host country government. That is, the number of IEAs in which a country participates provides a signal of its discount rate and thus influences its credit ceiling. Succinctly, the model implies that higher international environmental involvement is associated with more international exchange of credit. $^{10}$ 


\section{Addition of bilateral penalties}

The prediction of the analysis above is multilateral; when Ruritania signs its IEAs, all its potential sources of capital see this signal. We now add bilateral linkages across countries, consistent with the framework of Cole and Kehoe (1997). We assume that if Ruritania defaults, its creditors punish it in the environmental sphere. We then demonstrate that this possibility increases economic integration over and above the level sustained through multilateral IEA membership. In the next section, we take this prediction to the data to verify the empirical importance of spillovers across different forms of interaction.

Formally, we specify the bilateral punishment to debt default as reducing the net gains in each period from membership in IEAs in which both countries $i$ and $k$ are members by some fraction $\gamma, 0<\gamma \leq 1$, so that the gains from being in treaty $j$ are equal to $(1-\gamma)\left(v_{j}-e\right) .{ }^{11}$ An intermediate value of $\gamma$ may reflect a loss in cooperation between the two nations, while $\gamma=1$ would involve a "grim strategy," where the creditor nation responds to a default by its debtor by rescinding the treaty altogether. For simplicity, we assume that the value of $\gamma$ is constant across countries. $^{12}$

Define $m$ as the highest-numbered treaty in which both countries participate. With the addition of the bilateral treaty-based default penalty, the value of discounted utility under default satisfies

$$
\widehat{U}_{t}=y(\omega)+\left(\frac{1}{1-\beta}\right)\left\{x+\sum_{i=1}^{K}\left[y(\omega)-\omega r^{*}\right] \mid i \neq k+\int_{0}^{j^{*}}\left(1-\varphi_{j} \gamma\right)\left(v_{j}-e\right) f(j) d j\right\}(
$$

where $\varphi_{j}$ is an indicator variable that takes value 1 if $j \leq m$, and value 0 otherwise.

By (3) and (11), the credit constraint from country $k$ now satisfies 


$$
\beta y(\omega)-\omega r^{*}+\gamma \int_{0}^{j *} \varphi_{j}\left(v_{j}-e\right) f(j) d j \geq 0
$$

Comparing (12) and (9), it can be seen that the capacity to levy bilateral environmental treaty penalties under default eases the credit ceiling faced by country $k$. Moreover, the host country government will again choose $j^{*}$ such that (7) is still binding. Substituting and totally differentiating (13) with respect to $\omega$ and $j^{*}$ yields

$$
\frac{d \omega}{d j^{*}}=\frac{\partial v_{j^{*}}}{\partial j^{*}} \frac{e y(\omega)}{v_{j^{*}}\left(e y^{\prime}-r^{*} v_{j^{*}}\right)}-\frac{\varphi_{j^{*}} \gamma\left(v_{j^{*}}\right)^{2}\left(v_{j^{*}}-e\right) f\left(j^{*}\right)}{v_{j^{*}}\left(e y^{\prime}-r^{*} v_{j^{*}}\right)}>0
$$

Comparing (13) to (10), it can be seen that if $\varphi_{j^{*}}=1$, i.e., $j^{*} \leq m$, there is an additional positive term corresponding to the bilateral treaty penalty. When $j^{*} \leq m$ (that is, when adding an additional treaty increases the number of joint host-creditor treaties), the addition of bilateral penalties increases the sensitivity of the credit constraint to the number of treaties in which the host country is a member.

Given $j^{*}>m$, an increase in $m$ represents an increase in the number of jointly held treaties. Totally differentiating the credit constraint in (12) with respect to $\omega$ and $m$ yields

$$
\frac{d \omega}{d m}=-\frac{\gamma \varphi_{m}\left(v_{m}-e\right) v_{j^{*}} f(m)}{e y^{\prime}-r^{*} v_{j^{*}}} \geq 0
$$

when $\varphi_{m}=1$, i.e. when $j^{*}>m$, which implies that the bilateral credit constraint is also increasing in the number of treaties in which both the host country and the country of origin of the creditors are members.

Our theory therefore yields two nested predictions. The pure reputation model implies that the magnitude of flows from a source to the host country will be increasing in the total 
number of environmental treaties in which that country is a member. The bilateral punishment model also predicts that the magnitude of portfolio flows will be increasing in the number of jointly held treaties. In the following section, we test these predictions empirically.

\section{Empirics}

We think of the model above as illustrative rather than one to be taken literally. We have made a host of assumptions to keep the model stripped down to its bare essentials. For instance, the model assumes: no production or uncertainty, much symmetry, limited interactions between countries, and so forth. We think the analysis points to two key predictions. First, a country's non-economic commitments (which we model as the number of IEAs in which a country participates) should have a positive effect on its ability to conduct international economic exchange (which we model as international portfolio holdings). Second, bilateral non-economic interactions may also matter; the level of multilateral IEA participation may not be a sufficient statistic for the level of environmental engagement. The number of IEAs common to both countries is also relevant to their bilateral economic interactions if there are "bilateral penalties." We now take these predictions to the data.

\section{A. Specification}

Our pure reputation model predicts that the level of international asset cross-holdings between two nations will be increasing in the number of IEAs in which each of them participates, while the extended bilateral penalty model also predicts that the number of IEAs in which they are joint members is relevant. Our goal in this section is to check these predictions. 
Our empirical specification of international cross-holdings of assets is a generalization of the standard bilateral "gravity" model. While gravity specifications have been primarily applied to bilateral trade patterns, they have also been shown to explain bilateral financial flows surprisingly well [e.g. Rose and Spiegel $(2004,2007)$ and Portes and Rey (2005)]. Since transportation costs of moving assets are likely to be negligible, motivations for gravity specifications of financial flows in the literature have concentrated on information asymmetries. A theoretical justification for a gravity model for financial flows has been provided by Martin and Rey (2000), who develop a model of trade between countries with endogenously supplied assets that are imperfectly substitutable. International trade in these assets entails "iceberg" transactions costs that are increasing in the distance between the country where the asset is issued (which is also the location of the underlying real activity being financed) and the country where the asset is purchased. Martin and Rey argue that these costs capture a number of costs associated with international asset transactions, including banking commissions and fees, transactions fees associated with currency exchange, exposure to currency risk, and information costs.

Our specification satisfies:

$$
\begin{aligned}
& \ln \left(A_{i j}\right)=\beta_{1} \ln \left(D_{i j}\right)+\beta_{2 i} \ln \left(Y_{i}\right)+\beta_{2 j} \ln \left(Y_{j}\right)+\beta_{3 i} \ln \left(\text { Pop }_{i}\right)+\beta_{3 j} \ln \left(\text { Pop }_{j}\right) \\
& +\beta_{4} \text { RTA }_{i j}+\beta_{5} C U_{i j}+\beta_{6} \text { Lang }_{i j}+\beta_{7 i} \ln \left(\text { Area }_{i}\right)+\beta_{7 j} \ln \left(\text { Area }_{j}\right)+\beta_{8} \text { Cont }_{i j} \\
& +\beta_{8 i} \text { Landl }_{i}+\beta_{8 j} \text { Landl }_{j}+\beta_{9 i} \text { Island }_{i}+\beta_{9 j} \text { Island }_{j}+\beta_{10} \text { ComCol }_{i j} \\
& +\gamma_{1} \text { IEA }_{i j}+\gamma_{2} \text { IEA }_{i}+\beta_{11} \text { IEA }_{j}+\varepsilon_{i j}
\end{aligned}
$$

where $i$ denotes the host country, $j$ denotes the source country, and the variables are defined as:

- $\quad A_{i j}$ denotes asset cross-holdings held in host country $i$ and sourced from $j$, measured in (millions of US) dollars, 
- $\quad D_{i j}$ is the distance between $i$ and $j$,

- $Y_{i}$ is real GDP of $i$,

- $\quad P o p_{i}$ is population of $i$,

- $R T A_{i j}$ is a binary variable which is unity if $i$ and $j$ belong to the same regional trade agreement and zero otherwise,

- $C U_{i j}$ is a binary variable which is unity if $i$ and $j$ use the same currency at time t,

- Lang $_{i j}$ is a binary variable which is unity if $i$ and $j$ have a common language,

- $\quad$ Area $_{i}$ is the total area of $i$,

- Cont $_{i j}$ is a binary variable which is unity if $i$ and $j$ share a land border,

- Landl $_{i}$ is a binary variable which is unity if country $i$ is land-locked,

- Island ${ }_{i}$ is a binary variable which is unity if country $i$ is an island nation,

- Comcol $_{i j}$ is a binary variable which is unity if $i$ and $j$ were ever colonies after 1945 with the same colonizer,

- $I E A_{i}$ is the number of environmental treaties that $i$ has ratified at $\mathrm{t}$,

- $I E A_{i j}$ is the number of environmental treaties that $i$ and $j$ have both ratified at t,

- $\beta$ is a vector of nuisance coefficients, and

- $\varepsilon_{\mathrm{ij}}$ represents the other influences on bilateral credit, assumed to be well behaved.

The coefficients of interest to us are $\{\gamma\} \cdot \gamma_{1}$ represents the effect on international economic exchange of host country i's participation in international environmental treaties; $\gamma_{2}$ is the analogous effect of joint IEA participation by $i$ and $j$.

4B. Data 
Our regressand is asset cross-holdings. We use the Coordinated Portfolio Investment Survey (CPIS) data set, available annually for 2001, 2002, and 2003 from the IMF. ${ }^{13}$ This records cross-holdings of asset stocks between up to 68 source and 221 host "countries" measured in millions of US\$. The countries in the data set are listed in appendix table A1. To smooth the data out, we average our series across the years available, so that our data becomes a single bilateral cross-section.

As control variables, we merge in data on population and real GDP data (in constant dollars) taken from the World Bank's World Development Indicators. We exploit the CIA's World Factbook extensively for data on other regressors. ${ }^{14}$ From it we find series on: latitude and longitude, land area, landlocked and island status, physically contiguous neighbors, language, colonizers, and dates of independence. We use these to create great-circle distance and other controls. We obtain data from the World Trade Organization to create an indicator of regional trade agreements, including some 178 regional trade agreements. Finally, we add the Glick and Rose (2002) currency union dummy variable.

The coefficients of interest measure the effect of solo (multilateral) and joint (bilateral) participation in environmental treaties. Our data set on environmental treaties is the Environmental Treaties and Resource Indicators (ENTRI) data set produced by Columbia University. ${ }^{15}$ The ENTRI data set contains country-by-country indicators of participation in up to 464 treaties. The treaties range from the "Act regarding Navigation and Economic Cooperation between the States of the Niger Basin" through the "Vienna Convention on the Law of Treaties." The data set includes the usual suspects, including, e.g.: CITES (the "Convention on International Trade in Endangered Species of Wild Fauna and Flora"); Biodiversity 
("Convention on Biological Diversity"); and the Kyoto Protocol (to the United Nations Framework Convention on Climate Change).

ENTRI provides data for individual countries on: 1) which agreements the country has signed (so that a country is a "signatory" to a treaty); 2) which agreements are in force (where the country is a "party" to an agreement); as well as 3) agreements denounced (so that the country is a "former party" to a treaty). There are only a small number of the latter; almost one hundred countries have not denounced any agreements (the United States has denounced three agreements; and the United Kingdom has denounced the largest number of treaties, ten).

For our multilateral regressor $I E A_{i}$ (as well as $I E A_{j}$, which we use symmetrically as a control), we simply sum up the number of agreements either signed or in force, and subtract from this the number of denounced agreements. For our bilateral regressor $\left(I E A_{i j}\right)$ we sum up the number of agreements that are either signed or in force by both countries and subtract from this the number of jointly denounced agreements. Simply adding up the number of international environmental treaties is obviously a crude starting point, since treaties are not all of equal importance. We consider a more careful weighting of participation in different treaties to be an interesting topic for future work. ${ }^{16}$

Descriptive statistics for the key variables are presented in Table A2. Table A3 contains simple bivariate correlations between the key variables of interest. The regressors of interest are all positively correlated with the regressands.

\section{C. Results}

We begin by estimating our default equation with least squares, using standard errors that are robust to heteroskedasticity. ${ }^{17}$ Since our measure of a country's international environmental 
commitment is both measured with error and potentially simultaneously determined with asset flows, we also take instrumental variable results seriously; more on this later.

Our benchmark OLS results are presented in Table 1. The first column presents a specification in which only there are no environmental treaties entered at all. The next two columns add: first, the number of treaties to which each of the host and source countries separately belong (multilateral measures); and second, the number of environmental treaties to which both countries belong (a bilateral measure). The most important column is that on the right, which includes both the bilateral and multilateral measures of environmental treaties.

While the control variables are not of direct interest, it is reassuring to see that the default gravity model seems to work well. Countries that are further apart have fewer asset crossholdings, while countries with greater economic mass (as measured by GDP) have more. Holding GDP constant, countries with larger population (i.e., lower GDP per capita) exchange fewer assets. A number of sensible features seem to raise cross-holdings, including a common language, currency, land border, colonizer or regional trade agreement. Some of the purely geographic features (the physical size of a country, whether it is landlocked, and whether it is an island nation) also matter. The equation fits well, with an impressive $\mathrm{R}^{2}$ of .61 on a purely crosssectional basis.

Is there space for environmental commitment to matter above and beyond these factors? Yes. Both the multilateral and bilateral number of environmental commitments have a positive effect on asset cross-holdings. If one examines the column on the extreme right (which gives the weakest results since it examines multilateral and bilateral effects simultaneously), for each additional jointly signed environmental treaty, asset cross-holdings by $.03 \%$. This effect is small but plausible, and statistically significant at any reasonable confidence level. If a pair of 
countries were to move from the $25^{\text {th }}$ percentile (with 7 jointly signed environmental treaties) to the $75^{\text {th }}$ percentile (with 54 joint treaties) holding other factors constant, asset cross-holdings would be expected to rise by around $1.5 \%$. Similarly, the effect of a host country's environmental commitment also has a small positive and statistically significant effect on asset holdings; a one standard deviation increase in the number of environmental treaties signed raises asset cross-holdings by around .65\%.

We consider our OLS results to be basically supportive of the idea that non-economic partnerships play a small but positive role in supporting economic exchanges such as international cross-holdings of assets. Moreover, as we find that both multilateral and joint IEA memberships are significantly positive, the results appear to support some level of bilateral punishment as well.

\section{Instrumental Variables}

While we find our OLS results promising, we are reluctant to rely completely on them for at least two reasons. First, there is potential cause for concern with simultaneity. Participation in an environmental treaty requires a near-term sacrifice (for instance, the adherence costs associated with pollution abatement) for a stream of future benefits (associated with a more sustainable environment). Similarly, servicing international debt obligations also requires a short-term sacrifice for a long-term benefit. Both phenomena therefore involve a tradeoff between the benefits and costs of honoring long-run agreements; thus at some deep level, the two phenomena share important features. ${ }^{18}$ Measurement error is also a potentially serious issue, since a simple summation of the number of active environmental treaties in which a country is participating is a noisy indicator of its international environmental commitments. ${ }^{19}$ 
As our default we use two instrumental variables for the number of environmental agreements (we also experiment with other choices to check the robustness of our results). The first is the country's "polity" score, taken from the Polity IV data set. ${ }^{20}$ This is a score that measures the political nature of the country. It is available for 161 countries annually through 2003; the score for an individual country during a given year ranges from -10 (a high autocracy such as Qatar or Saudi Arabia) through 10 (a high democracy such as Australia or Austria). We think of this instrumental variable as desirable since more democratic political regimes are likely to have longer time horizons.

Our second instrumental variable is more directly tied to environmental considerations. We use the "Environmental Sustainability Index" (ESI), which was developed for the World Economic Forum by the Yale Center for Environmental Law and Policy and the Center for International Earth Science Information Network at Columbia University, and is available for up to 145 countries for 2001 and $2002 .^{21}$

The ESI is described by its creators as "a measure of overall progress towards environmental sustainability." A high ESI rank indicates that a country has achieved a higher level of environmental sustainability than most other countries; a low ESI rank signals that a country is facing substantial problems in achieving environmental sustainability along multiple dimensions. In 2001, the three countries with the highest and lowest ESI scores were Finland, Norway and Canada, and Haiti, Saudi Arabia, and Burundi respectively.

The ESI was designed to permit systematic quantitative international comparisons of environmental progress. It models environmental sustainability as a function of five phenomena: a) the state of the environmental systems, such as air, soil, ecosystems and water; b) the stresses on those systems, in the form of pollution and exploitation levels; c) the human vulnerability to 
environmental change in the form of loss of food resources or exposure to environmental diseases; d) the social and institutional capacity to cope with environmental challenges; and finally e) the ability to respond to the demands of global stewardship by cooperating in collective efforts to conserve international environmental resources such as the atmosphere. Accordingly, the ESI was constructed by aggregating five "core components" which each measure one of these phenomena; we also use the three most relevant of its components as instrumental variables for sensitivity analysis. These measure: 1) environmental systems; 2) environmental stress; and 3) human vulnerability to the environment. ${ }^{22,23}$

We think of the ESI and its underlying components as providing measures of actual and potential environmental damage. These are plausibly correlated with participation in environmental treaties because countries with more pollution are plausibly more sensitive to environmental costs and thus more likely to engage in IEAs; similarly, countries with greater potential losses from environmental degradation. These environmental measures do not seem closely related to a country's willingness to services its international debt, especially if they are caused by long-term geographic or historical features. However, we also examine alternative instrumental variables below.

Our IV results are presented in Table 2, which is formatted similarly to Table 1. Reassuringly, both coefficients of interest remain positive and statistically significant when estimated with IV. Indeed, consistent with the notion of either attenuation and/or simultaneity bias, the coefficients are even larger. The effect of joint environmental treaties has almost doubled while the effect of a host country's environmental treaties has more than quintupled! ${ }^{24}$ We tend to act conservatively in our interpretation and thus try not to take these magnitudes too literally, especially given that the precision of the estimates has deteriorated. ${ }^{25}$ Still, it seems 
reasonable to conclude that our positive OLS results do not stem simply from a flawed estimation strategy.

We check the sensitivity of our results further in Table 3. We pursue three types of robustness checks: 1) moving from time-averaged to annual data; 2) changing the instrumental variables; and 3) taking into account regional effects.

We are comfortable with our strategy of averaging our three years of data into a single cross-section. The span of the data is short so that the observations are highly dependent, and some country-pairs are not available for every year. Still, panel estimation is technically feasible. Accordingly, we estimated our equation by pooling our annual cross-sections, including year effects. The OLS and IV results are tabulated in the first two rows of Table 3. They indicate that our key finding of positive and significant effects of the number of both multilateral and joint (bilateral) environmental treaties on asset cross-holdings is robust to using pooled annual instead of a single cross-section of data.

The next rows experiment with the exact choice of instrumental variables. First, we substitute the three most plausible components of the ESI ("environmental systems," “environmental stress," and "human vulnerability") for the portmanteau ESI measure itself. ${ }^{26}$ Our two key coefficients of interest are still positive and significant when we follow this estimation strategy. The same is true when we replace the Polity and ESI IVs with the number of environmental treaties listed in the CIA's World Factbook. Appendix C of the Factbook tabulates 27 "Selected International Environmental Agreements"; we use the number of these as an instrumental variable for the total (from over 450) number of agreements listed by ENTRI, excluding only four that deal with the Antarctic. ${ }^{27}$ Again, our two key coefficients of interest remain positive and significant. 
We have checked our results further by using a completely different set of instrumental variables, derived from the World Bank's World Development Indicators (WDI) data set. In place of polity and the ESI, we use as IVs values of: a) “Adjusted savings from CO2 damage," and b) “Adjusted savings from particulate emission damage." These measure the effect on national savings of environmental damage (both are measured as percentages of gross national income) ${ }^{28}$ Carbon dioxide damage is estimated to be $\$ 20$ per ton of carbon (the unit damage in 1995 U.S. dollars) times the number of tons of carbon emitted; particulate emissions damage is calculated as the willingness to pay to avoid mortality attributable to particulate emissions. We choose these as measures of environmental damage that are available for a wide cross-section of countries. Importantly, we used values of these variables that are averaged over annual observations that are available between 1995 and 2000. Thus these instrumental variables measure environmental damage for a country years before the period of interest to us, which raises their plausibility as exogenous instrumental variables. Reassuringly, our coefficients remain positive and significantly different from zero.

Finally, $\gamma_{1}$ loses its statistical significance when we add three regional dummies (one for observations where either country is African; another for observations where either country is either Latin American or Caribbean; and a third where either country is Asian). On the other hand, the key multilateral effect remains positive and significant when regional dummies are included.

We conclude from all this that our finding of a positive and significant effect of IEA engagement on international cross-holdings of assets, is not particularly sensitive to the exact details of our econometric machinery. ${ }^{29}$ 


\section{D. A Different Data Set}

The CPIS data set used above corresponds to the international exchange of assets that we model in our theoretical section. However, it is most appropriately used as a single crosssection. This precludes employing panel data techniques, which might provide a sharper estimate of the effect of environmental engagement on economic exchange.

Accordingly, and for additional sensitivity analysis, we now examine a different data set, drawn from the BIS. This data set has strengths; it is an annual panel that stretches back to 1983, with over 40,000 observations that cover 25 source countries (or territories) and 205 host countries. It has weaknesses; it covers only bilateral consolidated international banking claims, and thus ignores many international assets exchanges. ${ }^{30}$ We supplement the banking data (which forms our regressand) with controls derived from the WDI (population and real GDP); ENTRI provides us with data on environmental treaties.

Using the notation of equation (15), our default estimating equation for the BIS data is:

$$
\begin{aligned}
\ln \left(\mathrm{C}_{\mathrm{ijt}}\right) & =\beta_{1} \ln (\mathrm{Y} / \mathrm{Pop})_{\mathrm{it}}+\beta_{2} \ln (\mathrm{Y} / \mathrm{Pop})_{\mathrm{jt}}+\beta_{3} \ln (\text { Pop })_{\mathrm{it}}+\beta_{4} \ln (\text { Pop })_{\mathrm{jt}} \\
& +\gamma_{1} \mathrm{IEA}_{\mathrm{ijt}}+\gamma_{2} \mathrm{IEA}_{\mathrm{it}}+\gamma_{3} \mathrm{IEA}_{\mathrm{jt}}+\left\{\delta_{\mathrm{t}}\right\}+\left\{\varphi_{\mathrm{ij}}\right\}+\varepsilon_{\mathrm{ijt}}
\end{aligned}
$$

where $\ln \left(\mathrm{C}_{\mathrm{ijt}}\right)$ is the natural logarithm of consolidated international claims made by banks from nationality $\mathrm{i}$ on country $\mathrm{j}$ during year $\mathrm{t}$.

This is a relatively conventional gravity equation; a number of the more conventional bilateral controls (such as distance or common language) are excluded since we include a comprehensive set of both (dyadic) country-pair-specific fixed effects, $\left\{\varphi_{\mathrm{ij}}\right\}$, as well as a comparable set of time-specific effects, $\left\{\delta_{t}\right\}$. Thus, we present "within" estimates that rely only 
on time-series variation in the effect of changes in treaty obligations on international banking claims, holding constant country size, income, and all features common to time or country-pairs. Default estimates of $\{\gamma\}$ are presented in the top rows of Table 4. There are three rows: the first only allows for joint effects of environmental engagement on economic exchange, the second only allows the unilateral effects, while the last allows for both. In our cross-sectional work of Tables 1-3, we found that both bilateral and unilateral effects seem to matter, and this finding also characterizes the panel results of Table 4. Indeed, each of the effects is positive and statistically significant at conventional significance levels; countries that participate in more treaties either by themselves or with others also enjoy greater international banking activity. We find the consistency of these panel results with the earlier cross-sectional CPIS results encouraging.

Table 4 also has contains four types of sensitivity analysis. First, we use country-specific random effects instead of fixed effects. As a second check, we replace the (dyadic) pair-specific fixed effects in (16) with a comprehensive set of (unilateral) country-specific fixed effects. ${ }^{31}$ Third, we estimate our equation with instrumental variables in place of OLS. ${ }^{32}$ Fourth, in place of using banking claims as our regressand, we merge in and substitute the stock of FDI stocks using OECD data. ${ }^{33}$ Most of these exercises show that our results are robust; in a few cases, the results are not statistically distinguishable from zero. In no case do environmental treaties enter with a significantly negative coefficient, either unilaterally or bilaterally. Overall, we find the panel data results consistent with our cross-sectional analysis and at least moderately reassuring.

We conclude from all this that there indeed seems to be a link between environmental engagement - as proxied through environmental treaty obligations - and international exchanges 
of assets. Moreover, this link appears to reflect both overall and joint IEA participation, suggesting that both the pure reputation and bilateral punishment channels for reputation spillovers play a role in the determination of cross-holdings of assets.

\section{Caveats, Summary and Conclusion}

In this paper, we first developed a theoretical model that suggests that countries more deeply enmeshed in international environmental arrangements should also find it easier to engage in international economic exchange with the rest of the world. We then showed that two countries with a joint interest in the environment should also find it easier to sustain large crossholdings of assets, since each can punish the other in one domain for transgressions in a different domain. We then tested these ideas, using a recent cross-section of international asset holdings, and environmental commitments. Our empirics verify the significance of both effects, especially the first; multilateral environmental engagement facilitates international economic exchange. A panel data set with bank loans and FDI provides further corroboration of our results, and our results are insensitive to a number of features of our methodology, including the assumption that IEA participation is either exogenous or correctly measured.

Is there a cost to "going it alone"? Is it costly for countries to ignore international environmental agreements? Yes. Countries have varying degrees of foreign engagement. Some are deeply enmeshed in defense alliances, environmental treaties, and international organizations; others are not. Above and beyond the direct consequences of such entanglements, we have found in this paper that countries with greater IEA participation also have higher trade in assets. Thus membership in international institutions brings indirect benefits; not joining such partnerships has costs. We chose to examine international environmental arrangements as one 
example of non-economic interactions. However, there are a variety of other domains in which countries interact; security arrangements and international organizations come to mind immediately.

If our assertions are correct, they have consequences for policy. For example, the debate on American participation in the Kyoto Protocol was framed in terms of the costs and benefits to the United States of participation in that treaty. If participation in such organizations also conveys indirect economic benefits, these externalities should not be ignored.

A number of questions remain: First, does bad behavior in the economic sphere (e.g., debt default) actually lead to retaliation outside the economic domain? For instance, do creditors punish defaulters through environmental means? More directly, what are the costs of violating IEAs? Do countries that violate international partnerships pay a cost, either indirect or direct? We leave such fascinating questions for future research. 


\section{References}

Alfaro, Laura and Fabio Kanczuk, (2005), "Sovereign debt as a Contingent Claim: A Quantitative Approach," Journal of International Economics, 65, 297-314.

Barrett, Scott (1994), "Self-Enforcing International Environmental Arrangements," Oxford Economic Papers, Special Issue on Environmental Economics, 46, 878-894.

Barrett, Scott (2003), Environment and Statecraft, (Oxford University Press, New York).

Bulow, Jeremy and Kenneth Rogoff (1989a) "A Constant Recontracting Model of Sovereign Debt” Journal of Political Economy 97(1), 155-178.

Bulow, Jeremy and Kenneth Rogoff (1989b) "Sovereign Debt: Is to Forgive to Forget?" American Economic Review 79, 43-50.

Carraro, Carlo, and Domenico Siniscalco (1997), "R\&D Cooperation and the Stability of International Environmental Agreements," in C. Carraro, ed., International Environmental Agreements: Strategic Policy Issues, (Elgar, Cheltenham).

Carraro, Carlo, and Domenico Siniscalco (1998), "International Environmental Agreements: Incentives and Political Economy," Journal of Public Economics, 42, 561-572.

Cole, Harold L., James Dow and William B. English, (1995), "Default, Settlement, and Signaling: Lending Resumption in a Reputational Model of Sovereign Debt, International Economic Review, 36(2), 365-385.

Cole, Harold L. and Patrick J. Kehoe (1995) "The Role of Institutions in Reputation Models of Sovereign Debt" Journal of Monetary Economics 35, 45-64.

Cole, Harold L. and Patrick J. Kehoe (1997) "Reviving Reputation Models of International Debt” Federal Reserve Bank of Minneapolis Quarterly Review 21(1), 21-30.

Cole, Harold L. and Patrick J. Kehoe (1998) "Models of Sovereign Debt: Partial vs. General Reputations" International Economic Review 39(1), 55-70.

Davies, Ronald B., and Helen T. Naughton (2006) "Cooperation in Environmental Policy: A Spatial Approach," mimeo, University of Oregon.

Drudi, Francesco and Alessandro Prati, (2000), "Signaling Fiscal Regime Sustainability," European Economic Review, 44, 1897-1930.

Eaton, Jonathan (1996) "Sovereign Debt, Reputation, and Credit Terms" International Journal of Finance and Economics 1, 25-36. 
Gale, Douglas and Martin Hellwig, (1989), "Repudiation and Renegotiation: The Case of Sovereign Debt," International Economic Review 30(1), 3-31.

Finus, Michael, Juan-Carlos Altamirano-Cabrera and Ekko C. Van Ierland, (2005), "The Effect of Membership Rules and Voting Schemes on the Success on International Climate Arrangements, Public Choice, 125, 95-127.

Kletzer, Kenneth M. and Brian D. Wright (2000) "Sovereign Debt as Inter-temporal Barter" American Economic Review, 90(3), 621-639.

Milde, Hellmuth and John G. Riley, (1988), "Signaling in Credit Markets," Quarterly Journal of Economics, 103, 1, 101-129.

Murdoch, James C., Todd Sandler and Wim P.M. Vijverberg, (2003), "The Participation Decision Versus the Level of Participation in an Environmental Treaty: A Spatial Probit analysis, Journal of Public Economics, 87, 337-362.

Krueger, Dirk, and Harald Uhlig (2003) "Competitive Risk-Sharing contracts with One-Sided Commitment” NBER Working Paper no. 10,135.

Martin, Philippe, and Hélène Rey (2000) "Financial Integration and Asset Returns" European Economic Review 44, 1327-1350.

Portes, Richard and Hélène Rey (2005) "The Determinants of Cross-Border Equity Flows," Journal of International Economics 65(2), 269-296.

Rose, Andrew K. and Mark M. Spiegel (2004) “A Gravity Model of Sovereign Lending: Trade, Default, and Credit," International Monetary Fund Staff Papers 51, 50-63.

Rose, Andrew K. and Mark M. Spiegel (2007) "Offshore Financial Centres: Parasites or Symbionts?” Economic Journal 117-523, 1310-35.

Sandleris, Guido, (2006), "Sovereign Defaults: Information, Investment and Credit," mimeo, Johns Hopkins University.

Spiegel, Mark M., “Solvency Runs, Sunspot Runs, and International Bailouts,” Journal of International Economics, 65, 203-219.

Wright, Mark (2002) "Reputations and Sovereign Debt,” mimeo, Stanford University. 
Table 1: OLS Results

\begin{tabular}{|c|c|c|c|c|}
\hline $\begin{array}{r}\text { \# Environmental } \\
\text { Treaties, Host }\end{array}$ & & $\begin{array}{l}.024 * * \\
(.001)\end{array}$ & & $\begin{array}{l}.013^{* *} \\
(.002)\end{array}$ \\
\hline $\begin{array}{r}\text { \# Environmental } \\
\text { Treaties, Joint }\end{array}$ & & & $\begin{array}{l}.048 * * \\
(.003)\end{array}$ & $\begin{array}{l}.032 * * \\
(.004)\end{array}$ \\
\hline Log Distance & $\begin{array}{c}-1.07 * * \\
(.08)\end{array}$ & $\begin{array}{c}-.85 * * \\
(.09)\end{array}$ & $\begin{array}{c}-.49 * * \\
(.09)\end{array}$ & $\begin{array}{c}-.59^{* *} \\
(.09)\end{array}$ \\
\hline $\begin{array}{r}\text { Log Host } \\
\text { Real GDP }\end{array}$ & $\begin{array}{c}3.51 * * \\
(.05)\end{array}$ & $\begin{array}{c}2.83 * * \\
(.07)\end{array}$ & $\begin{array}{c}2.95 * * \\
(.06)\end{array}$ & $\begin{array}{c}2.76 * * \\
(.07)\end{array}$ \\
\hline $\begin{array}{r}\text { Log Source } \\
\text { Real GDP }\end{array}$ & $\begin{array}{c}2.73 * * \\
(.09)\end{array}$ & $\begin{array}{c}2.33^{* *} \\
(.12)\end{array}$ & $\begin{array}{c}2.14^{* *} \\
(.10)\end{array}$ & $\begin{array}{c}2.26 * * \\
(.12)\end{array}$ \\
\hline $\begin{array}{r}\text { Log Host } \\
\text { Population }\end{array}$ & $\begin{array}{c}-2.27 * * \\
(.07)\end{array}$ & $\begin{array}{c}-1.72 * * \\
(.08)\end{array}$ & $\begin{array}{c}-1.84 * * \\
(.08)\end{array}$ & $\begin{array}{c}-1.67 * * \\
(.08)\end{array}$ \\
\hline $\begin{array}{c}\text { Log Source } \\
\text { Population } \\
\end{array}$ & $\begin{array}{c}-2.12^{* *} \\
(.10)\end{array}$ & $\begin{array}{c}-1.79 * * \\
(.12)\end{array}$ & $\begin{array}{c}-1.53 * * \\
(.11)\end{array}$ & $\begin{array}{c}-1.67^{* *} \\
(.12) \\
\end{array}$ \\
\hline $\begin{array}{r}\text { Regional Trade } \\
\text { Agreement }\end{array}$ & $\begin{array}{c}1.13 * * \\
(.16)\end{array}$ & $\begin{array}{c}1.20 * * \\
(.16)\end{array}$ & $\begin{array}{l}.69 * * \\
(.16)\end{array}$ & $\begin{array}{l}.89 * * \\
(.16)\end{array}$ \\
\hline Currency Union & $\begin{array}{c}3.17^{* *} \\
(.21)\end{array}$ & $\begin{array}{c}1.77^{* *} \\
(.24)\end{array}$ & $\begin{array}{l}.83 * * \\
(.25) \\
\end{array}$ & $\begin{array}{l}.90 * * \\
(.26) \\
\end{array}$ \\
\hline Common Language & $\begin{array}{c}1.83 * * \\
(.16)\end{array}$ & $\begin{array}{c}2.06^{* *} \\
(.16)\end{array}$ & $\begin{array}{c}1.97 * * \\
(.16)\end{array}$ & $\begin{array}{c}2.00^{* * *} \\
(.16)\end{array}$ \\
\hline Log Host Area & $\begin{array}{l}.13 * * \\
(.04)\end{array}$ & $\begin{array}{c}.01 \\
(.04) \\
\end{array}$ & $\begin{array}{l}-.00 \\
(.04) \\
\end{array}$ & $\begin{array}{l}-.03 \\
(.04) \\
\end{array}$ \\
\hline Log Source Area & $\begin{array}{c}-.26 * * \\
(.03)\end{array}$ & $\begin{array}{c}-.28 * * \\
(.03)\end{array}$ & $\begin{array}{c}-.44 * * \\
(.03)\end{array}$ & $\begin{array}{c}-.36^{* *} \\
(.04)\end{array}$ \\
\hline $\begin{array}{r}\text { Common Land } \\
\text { Border }\end{array}$ & $\begin{array}{l}.97 * * \\
(.36)\end{array}$ & $\begin{array}{l}.87^{*} \\
(.38)\end{array}$ & $\begin{array}{c}.56 \\
(.39)\end{array}$ & $\begin{array}{c}.61 \\
(.39)\end{array}$ \\
\hline $\begin{array}{r}\text { Host } \\
\text { Landlocked }\end{array}$ & $\begin{array}{c}-.56^{* *} \\
(.14)\end{array}$ & $\begin{array}{l}-.48 * * \\
(.14)\end{array}$ & $\begin{array}{l}-.29 * \\
(.14)\end{array}$ & $\begin{array}{l}-.36^{*} \\
(.14)\end{array}$ \\
\hline Source Landlocked & $\begin{array}{l}.35^{*} \\
(.18) \\
\end{array}$ & $\begin{array}{l}.43^{*} \\
(.18) \\
\end{array}$ & $\begin{array}{c}.28 \\
(.18) \\
\end{array}$ & $\begin{array}{l}.38^{*} \\
(.18)\end{array}$ \\
\hline $\begin{array}{r}\text { Host Island } \\
\text { Nation }\end{array}$ & $\begin{array}{l}.61 * * \\
(.18)\end{array}$ & $\begin{array}{l}.57 * * \\
(.18)\end{array}$ & $\begin{array}{l}.31 * * \\
(.17)\end{array}$ & $\begin{array}{l}.38^{*} \\
(.18)\end{array}$ \\
\hline Source Island Nation & $\begin{array}{c}1.37 * * \\
(.17)\end{array}$ & $\begin{array}{c}1.43 * * \\
(.17)\end{array}$ & $\begin{array}{c}1.27 * * \\
(.17)\end{array}$ & $\begin{array}{c}1.33 * * \\
(.17)\end{array}$ \\
\hline Common Colonizer & $\begin{array}{c}1.00^{* *} \\
(.41)\end{array}$ & $\begin{array}{c}1.81 * * \\
(.40)\end{array}$ & $\begin{array}{c}1.37^{* *} \\
(.39)\end{array}$ & $\begin{array}{c}1.66^{* *} \\
(.40)\end{array}$ \\
\hline $\begin{array}{c}\text { \# Environmental } \\
\text { Treaties, Source }\end{array}$ & & $\begin{array}{l}.009 * * \\
(.001)\end{array}$ & & $\begin{array}{c}.003 \\
(.001) \\
\end{array}$ \\
\hline Observations & 6432 & 6354 & 6432 & 6354 \\
\hline $\mathbf{R}^{2}$ & .61 & .63 & .63 & .63 \\
\hline Root MSE & 4.227 & 4.131 & 4.116 & 4.111 \\
\hline
\end{tabular}

Dependent variable: log asset cross-holdings. Columns estimated separately.

OLS with robust standard errors in parentheses.

Data averaged over 2001-2003.

Intercept included but not tabulated.

Coefficients that are significantly different from zero at .05 (01) are marked with one (two) asterisk(s). 
Table 2: IV Results

\begin{tabular}{|c|c|c|c|}
\hline $\begin{array}{r}\text { \# Environmental } \\
\text { Treaties, Host }\end{array}$ & $\begin{array}{l}.113 * * \\
(.007)\end{array}$ & & $\begin{array}{l}.077 * * \\
(.013)\end{array}$ \\
\hline $\begin{array}{r}\text { \# Environmental } \\
\text { Treaties, Joint }\end{array}$ & & $\begin{array}{l}.176^{* * *} \\
(.011)\end{array}$ & $\begin{array}{l}.057 * * \\
(.022)\end{array}$ \\
\hline Log Distance & $\begin{array}{l}-.02 \\
(.18)\end{array}$ & $\begin{array}{l}.98 * * \\
(.18)\end{array}$ & $\begin{array}{l}.28 \\
(.24)\end{array}$ \\
\hline $\begin{array}{r}\text { Log Host } \\
\text { Real GDP } \\
\end{array}$ & $\begin{array}{l}.12 \\
(.22) \\
\end{array}$ & $\begin{array}{c}1.10 * * \\
(.16)\end{array}$ & $\begin{array}{c}.40 \\
(.21) \\
\end{array}$ \\
\hline $\begin{array}{r}\text { Log Source } \\
\text { Real GDP }\end{array}$ & $\begin{array}{l}-.25 \\
(.78)\end{array}$ & $\begin{array}{l}.61^{* *} \\
(.18)\end{array}$ & $\begin{array}{c}.25 \\
(.73)\end{array}$ \\
\hline $\begin{array}{r}\text { Log Host } \\
\text { Population }\end{array}$ & $\begin{array}{c}.07 \\
(.17) \\
\end{array}$ & $\begin{array}{c}-.60 * * \\
(.13) \\
\end{array}$ & $\begin{array}{l}-.12 \\
(.16)\end{array}$ \\
\hline $\begin{array}{c}\text { Log Source } \\
\text { Population } \\
\end{array}$ & $\begin{array}{r}.34 \\
(.60) \\
\end{array}$ & $\begin{array}{l}.10 \\
(.18)\end{array}$ & $\begin{array}{l}.10 \\
(.57)\end{array}$ \\
\hline $\begin{array}{r}\text { Regional Trade } \\
\text { Agreement }\end{array}$ & $\begin{array}{c}1.85 * * \\
(.22)\end{array}$ & $\begin{array}{l}-.04 \\
(.22)\end{array}$ & $\begin{array}{c}1.24 * * \\
(.30)\end{array}$ \\
\hline Currency Union & $\begin{array}{c}-3.15 * * \\
(.64)\end{array}$ & $\begin{array}{c}-4.91 * * \\
(.70)\end{array}$ & $\begin{array}{c}-3.73 * * \\
(.73)\end{array}$ \\
\hline Common Language & $\begin{array}{c}3.09 * * \\
(.29)\end{array}$ & $\begin{array}{c}2.13^{* *} \\
(.21)\end{array}$ & $\begin{array}{c}2.74 * * \\
(.27)\end{array}$ \\
\hline Log Host Area & $\begin{array}{l}.34 * * \\
(.07)\end{array}$ & $\begin{array}{c}.06 \\
(.05)\end{array}$ & $\begin{array}{l}.26 * * \\
(.07)\end{array}$ \\
\hline Log Source Area & $\begin{array}{c}.07 \\
(.10)\end{array}$ & $\begin{array}{l}-.33 * * \\
(.06)\end{array}$ & $\begin{array}{l}-.08 \\
(.09)\end{array}$ \\
\hline $\begin{array}{r}\text { Common Land } \\
\text { Border }\end{array}$ & $\begin{array}{c}.28 \\
(.65)\end{array}$ & $\begin{array}{l}-1.13 \\
(.62)\end{array}$ & $\begin{array}{l}-.19 \\
(.65)\end{array}$ \\
\hline $\begin{array}{r}\text { Host } \\
\text { Landlocked }\end{array}$ & $\begin{array}{c}.06 \\
(.20)\end{array}$ & $\begin{array}{l}.42 * \\
(.18)\end{array}$ & $\begin{array}{c}.18 \\
(.19)\end{array}$ \\
\hline Source Landlocked & $\begin{array}{c}1.09 * * \\
(.38)\end{array}$ & $\begin{array}{l}.79 * * \\
(.26)\end{array}$ & $\begin{array}{l}.91 * \\
(.36)\end{array}$ \\
\hline $\begin{array}{r}\text { Host Island } \\
\text { Nation } \\
\end{array}$ & $\begin{array}{c}1.10 * * \\
(.35) \\
\end{array}$ & $\begin{array}{l}-.35 \\
(.31) \\
\end{array}$ & $\begin{array}{c}.65 \\
(.38) \\
\end{array}$ \\
\hline Source Island Nation & $\begin{array}{c}1.79 * * \\
(.49)\end{array}$ & $\begin{array}{c}.18 \\
(.27) \\
\end{array}$ & $\begin{array}{c}1.16^{* *} \\
(.44)\end{array}$ \\
\hline Common Colonizer & $\begin{array}{l}6.22 \\
(.88)\end{array}$ & $\begin{array}{l}4.53 * * \\
(.80)\end{array}$ & $\begin{array}{c}5.66^{* *} \\
(.82)\end{array}$ \\
\hline $\begin{array}{c}\text { \# Environmental } \\
\text { Treaties, Source }\end{array}$ & $\begin{array}{l}.060 * * \\
(.012)\end{array}$ & & $\begin{array}{l}.037 * * \\
(.011)\end{array}$ \\
\hline Observations & 4430 & 4430 & 4430 \\
\hline $\mathbf{R}^{2}$ & .40 & .55 & .50 \\
\hline Root MSE & 5.288 & 4.552 & 4.822 \\
\hline
\end{tabular}

Dependent variable: log asset cross-holdings. Columns estimated separately.

IV with robust standard errors in parentheses. Polity and ESI (host\&source/product/both) as IVs.

Data averaged over 2001-2003.

Intercept included but not tabulated.

Coefficients that are significantly different from zero at .05 (01) are marked with one (two) asterisk(s). 
Table 3: Sensitivity Analysis

\begin{tabular}{|l|c|c|}
\hline & $\begin{array}{c}\text { \# Environmental } \\
\text { Treaties, Host }\end{array}$ & $\begin{array}{c}\text { \# Environmental } \\
\text { Treaties, Joint }\end{array}$ \\
\hline OLS, Annual Panel with & $.006^{* *}$ & $.042^{* *}$ \\
year effects & $(.002)$ & $(.003)$ \\
\hline IV, Annual Panel with & $.062^{* *}$ & $.065^{* *}$ \\
year effects & $(.011)$ & $.018)$ \\
\hline IV, Polity and 3 ESI & $.028^{* *}$ & $.094^{* *}$ \\
components as IVs & $(.006)$ & $.013)$ \\
\hline IV, CIA Treaties as IVs & $.018^{* *}$ & $.028^{* *}$ \\
& $(.002)$ & $(.006)$ \\
\hline IV, WDI IVs & $.048^{* *}$ & $(.005)$ \\
\hline IV, WDI IVs & & $.135^{* *}$ \\
& $.024^{*}$ & $.018)$ \\
\hline IV, WDI IVs & $(.011)$ & $(.025)$ \\
\hline IV, with regional dummies & $.080^{* *}$ & .024 \\
& $(.013)$ & $(.023)$ \\
\hline
\end{tabular}

Dependent variable: log asset cross-holdings. Rows estimated separately. Data averaged over 2001-2003 unless noted. Robust standard errors in parentheses. Coefficients that are significantly different from zero at .05 (01) are marked with one (two) asterisk(s).

Other controls included but not reported: \#Source Environmental Treaties (where appropriate), Log Distance, Log Host Real GDP, Log Source Real GDP, Log Host Population, Log Source Population, Regional Trade Agreement, Currency Union, Common Language, Log Host Area, Log Source Area, Common Land Border, Host Landlocked, Source Landlocked, Host Island Nation, Source Island Nation, Common Colonizer, and intercept. Polity and ESI (host\&source/product/both) are default IVs. WDI IVs: 1995-2000 averages of WDI Adjusted savings from $\mathrm{CO} 2$ and particulate emission damage (\% GNI), (host\&source/product/both). 
Table 4: Panel Results on BIS Consolidated Banking Claims

\begin{tabular}{|c|c|c|c|}
\hline & $\begin{array}{c}\text { \# Environ } \\
\text { Treaties, Joint }\end{array}$ & $\begin{array}{c}\text { \# Environ } \\
\text { Treaties, Host }\end{array}$ & $\begin{array}{c}\# \text { Environ } \\
\text { Treaties, Source }\end{array}$ \\
\hline Default & $\begin{array}{l}.23 * * \\
(.03)\end{array}$ & & \\
\hline Default & & $\begin{array}{l}.19 * * \\
(.03)\end{array}$ & $\begin{array}{l}37 * * \\
(.10)\end{array}$ \\
\hline Default & $\begin{array}{l}.10^{*} \\
(.04) \\
\end{array}$ & $\begin{array}{l}.18 * * \\
(.04) \\
\end{array}$ & $\begin{array}{l}.30 * * \\
(.10) \\
\end{array}$ \\
\hline Random Effects & $\begin{array}{l}.25 * * \\
(.03)\end{array}$ & & \\
\hline Random Effects & & $\begin{array}{l}.20 * * \\
(.03) \\
\end{array}$ & $\begin{array}{l}17 * * \\
(.08) \\
\end{array}$ \\
\hline Random Effects & $\begin{array}{l}.13 * * \\
(.04)\end{array}$ & $\begin{array}{l}.16^{* *} \\
(.04)\end{array}$ & $\begin{array}{l}.09 * * \\
(.09)\end{array}$ \\
\hline Country-Specific (not dyadic) FE & $\begin{array}{l}.22 * * \\
(.06)\end{array}$ & & \\
\hline Country-Specific (not dyadic) FE & & $\begin{array}{l}.19 * * \\
(.06) \\
\end{array}$ & $\begin{array}{l}.41 * \\
(.18) \\
\end{array}$ \\
\hline Country-Specific (not dyadic) FE & $\begin{array}{c}.12 \\
(.08) \\
\end{array}$ & $\begin{array}{l}.16 \\
(.09)\end{array}$ & $\begin{array}{c}.34 \\
(.19) \\
\end{array}$ \\
\hline IV & $\begin{array}{c}2.50 * * \\
(.68)\end{array}$ & & \\
\hline IV & & $\begin{array}{c}2.48 * * \\
(.55)\end{array}$ & $\begin{array}{l}-.74 \\
(.49) \\
\end{array}$ \\
\hline IV & $\begin{array}{l}-1.70 \\
(1.48) \\
\end{array}$ & $\begin{array}{l}3.57 * * \\
(1.39)\end{array}$ & $\begin{array}{c}.91 \\
(1.25) \\
\end{array}$ \\
\hline FDI, default specification & $\begin{array}{l}.41 * * \\
(.05)\end{array}$ & & \\
\hline FDI, default specification & & $\begin{array}{l}.37 * * \\
(.07) \\
\end{array}$ & $\begin{array}{l}.58 * * \\
(.16) \\
\end{array}$ \\
\hline FDI, default specification & $\begin{array}{l}.37 * * \\
(.08)\end{array}$ & $\begin{array}{c}.03 \\
(.10) \\
\end{array}$ & $\begin{array}{l}.33 * \\
(.17)\end{array}$ \\
\hline
\end{tabular}

Dependent variable: log consolidated bank claims (million \$), or log outward FDI stock from OECD (million \$). Annual data spanning 1983-1999 for 206 countries.

Country-pair-specific (dyadic) fixed effect estimation (except where noted).

Coefficient is effect on \#joint/host/source environmental treaties. Standard errors in parentheses; coefficients that are significantly different from zero at .05 (.01) are marked with one (two) asterisk(s).

Regressors included but not recorded: log population (both host and source); log real GDP per capita (both host and source); log product of areas; dummies for \#landlocked, \#islands, common language, common colonizer, common country, colonial history; and time-specific dummies.

Instrumental variables for \#joint environmental treaties are: a) product of source and host country $\mathrm{CO} 2$ emissions; b) product of source and host organic water pollution; c) product of source and host country particle emissions.

Instrumental variables for \# source/ host environmental treaties are: a) \# of source/host country CO2 emissions; b) \# of source/host organic water pollution; c) \# of source/host country particle emissions. 


\section{Appendix.}

\section{Conditions for separating equilibrium}

We can rule out a pooling equilibrium if no individual country would choose to deviate from its separating equilibrium solution to mimic a more patient government. We first examine the case where there are no bilateral penalties. Suppose that the government chose a value of $j>j *$ in period 0 . This would increase $\omega^{k}$ and violate the credit condition (8), inducing the host country to declare a multilateral default on all of its creditors. However, if $j-j^{*}$ is small, (6) implies that the fixed penalty from treaty violation ensures compliance with all $j$ treaties. By (4) and (6)

$$
\lim _{j \rightarrow j^{*}} U_{t}-\widehat{U}_{t}=\left(\frac{\beta \phi}{1-\beta}\right) \int_{j^{*}-1}^{j^{*}} f(j) d j>0
$$

By (9), the change in discounted utility of a small increase in $j$ beyond $j *$ then satisfies

$$
U_{j}-U_{j^{*}}=\sum_{i=1}^{K} \int_{j^{*}}^{j} \frac{\partial v_{j}}{\partial j} \frac{e y^{\prime} y}{\left(v_{j}\right)^{2}\left(e y^{\prime}-r^{*}\right)} f(z) d z+\left(\frac{1}{1-\beta}\right) \int_{j^{*}}^{j}\left(\beta v_{z}-e\right) f(z) d z
$$

The first term is positive, reflecting the increased output in the next period due to the increase in credit constraint, while the second term is negative, reflecting the cost of entering into undesirable treaties. For the entire term to be negative, the second term must be larger than the first. This condition is more likely to be satisfied the less sensitive is the credit constraint to the number of treaties joined and the steeper is the rate of decline in treaty payoffs with increases in $j$

Note that this condition will be violated at the margin, as by (4) the second term goes to 0 as $j \rightarrow j^{*}$. This implies that to rule out any mimicking behavior it must be the case that treaties are "lumpy," in the sense that joining an additional treaty moves one a discrete distance away from the margin. At the optimum, one would always choose to do some amount of mimicking as the gains of doing so are first order, while the losses from mimicking are second order. However, as treaties are discrete in practice, this does not pose a major concern.

The condition for a separating equilibrium in the presence of bilateral default penalties is similar. As before, if the host country government joins $j>j *$ treaties, its true credit constraint would be violated and it will choose to default. The only distinction is that the gains from treaty participation would also be reduced as a result of the bilateral default penalty.

As before, for small increases in $j^{*}$ the fixed penalty will induce the host country to comply with all of its signed treaties. The gains from joining $j>j^{*}$ treaties with bilateral punishment then satisfy 


$$
U_{j}-U_{j^{*}}=\sum_{i=1}^{K} \int_{j^{*}}^{j} \frac{\partial v_{j}}{\partial j} \frac{e y^{\prime} y}{\left(v_{j}\right)^{2}\left(e y^{\prime}-r^{*}\right)} f(z) d z+\left(\frac{1}{1-\beta}\right)\left[\int_{j^{*}}^{j}\left(\beta v_{z}-e\right) f(z) d z-\varphi_{z} \gamma \int_{0}^{j^{*}}\left(\beta v_{z}-e\right) f(z) d z\right]
$$

Comparing equations (A-2) and (A-3), it can be seen that the condition for ruling out the pooling equilibrium is less restrictive due to the additional bilateral penalties that would be levied on countries mimicking more patient governments. These are represented by the additional bracketed term in (A-3). 
Table A1: Host Countries in CPIS Data Set

\begin{tabular}{|c|c|c|c|c|}
\hline Afghanistan & Albania & Algeria & American Samoa & Andorra \\
\hline Angola & Anguilla & Antigua and Barbuda & Argentina* & Armenia \\
\hline Aruba* & Australia* & Austria* & Azerbaijan & Bahamas* \\
\hline Bahrain* & Bangladesh & Barbados & Belarus & Belgium* \\
\hline Belize & Benin & Bermuda & Bhutan & Bolivia \\
\hline Bosnia and Herzegovina & Botswana & Brazil & British Virgin Islands & Brunei Darussalam \\
\hline Bulgaria* & Burkina Faso & Burundi & Cambodia & Cameroon \\
\hline Canada* & Cape Verde & Cayman Islands* & Central African Rep. & Chad \\
\hline Chile* & China & Colombia* & Comoros & Congo (Zaire/Kinshasa) \\
\hline Congo (Brazzaville) & Cook Islands & Costa Rica* & Côte d'Ivoire & Croatia \\
\hline Cuba & Cyprus* & Czech Republic* & Denmark* & Djibouti \\
\hline Dominica & Dominican Republic & Ecuador & Egypt* & El Salvador \\
\hline Equatorial Guinea & Eritrea & Estonia* & Ethiopia & Falkland Islands \\
\hline Faeroe Islands & Fiji & Finland* & France* & French Guiana \\
\hline French Polynesia & Gabon & Gambia & Georgia & Germany* \\
\hline Ghana & Gibraltar & Greece* & Greenland & Grenada \\
\hline Guadeloupe & Guam & Guatemala & Guernsey* & Guinea \\
\hline Guinea-Bissau & Guyana & Haiti & Honduras & Hong Kong* \\
\hline Hungary* & Iceland* & India & Indonesia* & Iran \\
\hline Iraq & Ireland* & Isle of Man* & Israel* & Italy* \\
\hline Jamaica & Japan* & Jersey* & Jordan & Kazakhstan* \\
\hline Kenya & Kiribati & Korea* & Kuwait & Kyrgyz Republic \\
\hline Laos & Latvia & Lebanon* & Lesotho & Liberia \\
\hline Libya & Liechtenstein & Lithuania & Luxembourg* & Macau* \\
\hline Macedonia & Madagascar & Malawi & Malaysia* & Maldives \\
\hline Mali & Malta* & Marshall Islands & Martinique & Mauritania \\
\hline Mauritius* & Mexico & Micronesia & Moldova & Monaco \\
\hline Mongolia & Montserrat & Morocco & Mozambique & Myanmar \\
\hline Namibia & Nauru & Nepal & Netherlands* & Netherlands Antilles* \\
\hline New Caledonia & New Zealand* & Nicaragua & Niger & Nigeria \\
\hline North Korea & Norway* & Oman & Pakistan* & Palau \\
\hline Panama* & Papua New Guinea & Paraguay & Peru & Philippines* \\
\hline Poland* & Portugal* & Puerto Rico & Qatar & Réunion \\
\hline Romania* & Russian Federation* & Rwanda & St. Helena & St. Kitts and Nevis \\
\hline St. Lucia & St. Pierre \& Miquelon & St. Vincent \& Gren. & Samoa & San Marino \\
\hline São Tomé and Príncipe & Saudi Arabia & Senegal & Serbia and Montenegro & Seychelles \\
\hline Sierra Leone & Singapore* & Slovak Republic* & Slovenia & Solomon Islands \\
\hline Somalia & South Africa* & Spain* & Sri Lanka & Sudan \\
\hline Suriname & Swaziland & Sweden* & Switzerland* & Syrian Arab Republic \\
\hline Taiwan & Tajikistan & Tanzania & Thailand* & Togo \\
\hline Tonga & Trinidad and Tobago & Tunisia & Turkey* & Turks \& Caicos Islands \\
\hline Turkmenistan & Tuvalu & Uganda & Ukraine* & United Arab Emirates \\
\hline United Kingdom* & United States* & Uruguay* & Uzbekistan & Vanuatu* \\
\hline Venezuela* & Vietnam & Virgin Islands & Yemen & Zambia \\
\hline Zimbabwe & & & & \\
\hline
\end{tabular}

Note: Source countries also marked with an asterisk. 
Table A2: Descriptive Statistics

\begin{tabular}{|c|c|c|c|c|c|}
\hline & Obs. & Mean & Std. Dev. & Min & Max \\
\hline Log Assets & 9,396 & -3.33 & 6.62 & -9.21 & 13.20 \\
\hline \# Environmental Treaties, Joint & 14,960 & 38.47 & 32.53 & 0 & 232 \\
\hline \# Environmental Treaties, Host & 13,403 & 78.08 & 50.09 & 1 & 278 \\
\hline \# Environmental Treaties, Source & 13,420 & 125.4 & 60.75 & 1 & 278 \\
\hline Log Distance & 14,960 & 7.91 & .75 & 3.18 & 9.27 \\
\hline Log Host Real GDP & 10,242 & 17.37 & 2.09 & 12.85 & 23.03 \\
\hline Log Source Real GDP & 11,710 & 18.90 & 1.72 & 13.27 & 23.03 \\
\hline Log Host Population & 11,862 & 8.56 & 2.08 & 3.00 & 14.06 \\
\hline Log Source Population & 12,200 & 9.19 & 1.97 & 4.15 & 12.57 \\
\hline Regional Trade Agreement & 14,960 & .106 & .31 & 0 & 1 \\
\hline Currency Union & 14,960 & .014 & .12 & 0 & 1 \\
\hline Common Language & 14,960 & .19 & .39 & 0 & 1 \\
\hline Log Host Area & 14,960 & 10.63 & 3.20 & .69 & 16.65 \\
\hline Log Source Area & 14,960 & 11.11 & 3.20 & 3.04 & 16.65 \\
\hline Common Land Border & 14,960 & .01 & .12 & 0 & 1 \\
\hline Host Landlocked & 14,960 & .17 & .37 & 0 & 1 \\
\hline Source Landlocked & 14,960 & .08 & .28 & 0 & 1 \\
\hline Host Island Nation & 14,960 & .21 & .41 & 0 & 1 \\
\hline Source Island Nation & 14,960 & .20 & .40 & 0 & 1 \\
\hline Common Colonizer & 14,960 & .07 & .26 & 0 & 1 \\
\hline Host Polity & 10,487 & 3.21 & 6.64 & -10 & 10 \\
\hline $\begin{array}{r}\text { Source Polity } \\
\end{array}$ & 11,660 & 7.68 & 4.42 & -7 & 10 \\
\hline Product, Host and Source Polity & 8,162 & 24.47 & 60.52 & -100 & 100 \\
\hline $\begin{array}{ll}\text { Host ESI } \\
\end{array}$ & 9,605 & 49.45 & 9.02 & 23.9 & 73.9 \\
\hline $\begin{array}{r}\text { Source ESI } \\
\end{array}$ & 11,220 & 54.36 & 9.08 & 35 & 73.9 \\
\hline Product, Host and Source ESI & 7,191 & 2687.2 & 666.7 & 836.5 & 5394.7 \\
\hline
\end{tabular}

Data averaged over 2001-03.

Table A3: Bivariate Correlations

\begin{tabular}{|r|c|c|c|}
\hline & $\begin{array}{c}\text { Log } \\
\text { Assets }\end{array}$ & $\begin{array}{c}\text { \# Joint } \\
\text { Env. Trts }\end{array}$ & $\begin{array}{c}\text { \# Host } \\
\text { Env. Tr. }\end{array}$ \\
\hline \# Environmental Treaties, Joint & .70 & & \\
\hline \# Environmental Treaties, Host & .63 & .78 & \\
\hline Host Polity & .48 & .49 & .56 \\
\hline Product, Host and Source Polity & .47 & .52 & .49 \\
\hline Host ESI & .33 & .36 & .40 \\
\hline Product, Host and Source ESI & .23 & .30 & .29 \\
\hline
\end{tabular}

\footnotetext{
4,636 observations
} 
Table A4: First Stage for Bilateral Equation

\begin{tabular}{|r|c|c|}
\hline & $\begin{array}{c}\text { \# Environmental } \\
\text { Treaties, Joint }\end{array}$ & $\begin{array}{c}\text { \# Environmental } \\
\text { Treaties, Host }\end{array}$ \\
\hline Host Polity & -.24 & $2.91^{* *}$ \\
& $(.18)$ & $(.29)$ \\
\hline Source Polity & .02 & -.11 \\
& $(.18)$ & $(.31)$ \\
\hline Product, Host and & $.12^{* *}$ & $-.14^{* *}$ \\
Source Polity & $(.02)$ & $(.03)$ \\
\hline Host ESI & .16 & .54 \\
& $(.22)$ & $(.35)$ \\
\hline Source ESI & -.08 & -.20 \\
& $(.19)$ & $(.32)$ \\
\hline Product, Host and & .004 & .002 \\
Source ESI & $(.004)$ & $.006)$ \\
\hline Test: 6 IVs=0 (p-val) & .00 & .00 \\
\hline $\mathbf{R}^{2}$ & .72 & .67 \\
\hline
\end{tabular}

Other controls included but not reported: Log Distance, Log Host Real GDP, Log Source Real GDP, Log Host Population, Log Source Population, Regional Trade Agreement, Currency Union, Common Language, Log Host Area, Log Source Area, Common Land Border, Host Landlocked, Source Landlocked, Host Island Nation, Source Island Nation, Common Colonizer, and intercept.

Columns estimated separately. Standard errors in parentheses. Data averaged over 2001-2003. 4430 Observations. Coefficients that are significantly different from zero at .05 (01) are marked with one (two) asterisk(s). 


\section{Endnotes}

${ }^{1}$ A cautionary note: there is little evidence of punishment of any form for transgressions in international economic exchange. However, as our model is deterministic, punishment is not observed along equilibrium paths.

${ }^{2}$ In practice, evidence of punishment of any form for transgressions in international economic exchange is limited, and the form of punishment posited in this paper is no exception. Still, there are a number of recent examples of perceived linkages across different categories of commitments: In 2004, Argentine President Kirchner addressed a Kyoto Protocol conference, saying it was "unacceptable" that third-world countries should be held to the terms of their outstanding debts while first-world countries, such as the United States, had failed to fulfill their obligations to stop global warming. The speech implied a link between political cooperation and international credit relationships. In the case of trade relationships, we also see evidence of spillovers with non-economic partnerships. For example, Russian President Putin openly tied Russian ratification of the Kyoto Protocol to European Union support for Russian accession to the World Trade Organization.

${ }^{3}$ There have been other approaches to the challenge raised by Bulow and Rogoff (1989b). Some have concentrated on the ability of another creditor to step in and allow for self-finance subsequent to default. Eaton (1996) and Kletzer and Wright (2000) examine the implications of limiting the commitment capabilities of creditors in sovereign debt models to the level of their debtors. Wright (2002) concentrates on the possibility that the alternative Swiss bankers may not be available for the pursuit of self-finance if creditors find it optimal to collude against a borrower with a history of default. Krueger and Uhlig (2003) examine relationships where creditors have the ability to commit to making contingent payments, but there is a positive cost of initiating a credit relationship that limits a borrower's ability to switch creditors subsequent to a default. All of these generalizations concerning alternative financing opportunities defang the Bulow-Rogoff problem sufficiently to allow sovereign borrowing to reemerge.

${ }^{4}$ We considered adding an interactive term to our empirical specification to allow the number of jointly-held treaties between two countries to be of decreasing importance with the distance between those countries. However, this specification encountered empirical challenges as this interactive term was highly correlated with the raw number of jointly-held treaties, one of our variables of interest. As such, we left geographic considerations for future research.

${ }_{5}^{5}$ In our data set, there are simultaneous bilateral portfolio investments in each direction. We make no attempt to motivate these here, as for our purposes it is sufficient that foreign investors exist who are willing to make investments as long as the expected rate of return meets or exceeds some minimal rate, which we set at the risk free rate here (without loss of generality). However, one could motivate these cross-haulings of portfolio investments in terms of diversification motives.

${ }^{6} \mathrm{We}$ allow for selective default to facilitate ease of comparison with the bilateral analysis that follows; allowing only for multilateral default would produce the same result.

${ }^{7}$ The relationship between government and private default decisions is typically associated with the so-called "sovereign ceiling," which limits a private borrower's creditworthiness to less than or equal to the perceived creditworthiness of the borrower's government. This ceiling is motivated by episodes such as the 1982 Mexican default, which applied to all public and private Mexican obligations. In practice, the relationship between sovereign and private ratings is more complicated, as ratings on top private issues sometimes exceed the values assigned to issues by their sovereign. Still, these public and private issues are highly correlated, suggesting the perception that default risk on public and private obligations is linked.

${ }^{8}$ The endowment implicitly includes a number of arguments that we take as exogenous to the government's default decision, including net proceeds from foreign investments.

${ }^{9}$ Our specification implicitly sets a zero penalty on debt default for notational simplicity. However, we could easily extend our analysis to include penalties for debt default as well. Under this alternative specification, countries could sustain some level of positive borrowing without any IEA participation, but the amount of borrowing that could be sustained would still be increasing in both unilateral and multilateral IEA participation.

${ }^{10}$ This raises the possibility that a country might join more than its optimal number of IEAs in order to signal (misleadingly) that it is more patient, and thus ease its credit ceiling. We derive the conditions necessary to rule out this pooling equilibrium in an appendix.

${ }^{11}$ The use of bilateral penalties ensures that our result that the host country would not choose to renege on environmental treaties that it voluntarily joins is maintained. This might be changed if the penalties were levied on the gross, rather than the net, benefits of the treaty, where the government would now choose to renege on some marginal treaties, in particular on treaty $j^{*}$.

${ }^{12}$ The capacity to punish partners may differ across countries. For example, a large country may be able to influence treaty policies more than a small one. However, as influence may differ in a number of unknown 
dimensions, we do not attempt to introduce any explicit heterogeneity in punishment technology across countries, although we do condition for other attribute differences, such as country size, in our empirical specification.

${ }^{13} \mathrm{http}: / / \mathrm{www}$.imf.org/external/np/sta/pi/cpis.htm. The CPIS data set has its foibles; for instance, a number of entries are missing. Since a large number of asset cross-holdings are reported to be zero, we add .0001 to these

observations.

${ }^{14} \mathrm{http} / / /$ www.cia.gov/cia/publications/factbook/

${ }^{15} \mathrm{http}: / /$ sedac.ciesin.columbia.edu/entri/

${ }^{16}$ In the model above, our ability to monotonically order the IEAs in terms of desirability implied that if $j^{*}>j_{i}{ }^{*}$ an increase in $j^{*}$ would have no impact on $m^{\mathrm{i}}$. In the data, however, countries are likely to have heterogeneous preferences across treaties for a variety of reasons, allowing $j^{*}$ and $m^{\mathrm{i}}$ to vary independently. We therefore treat these variables as independent in our empirical analysis.

${ }^{17}$ Clustering our standard errors by either host or source country makes little difference to their statistical significance.

${ }^{18}$ We thank a referee for making this point forcefully to us.

${ }^{19}$ Measurement error likely exists in a number of dimensions: Other international organizations, such as the European community, also contain environmental accords. Alternatively, the United States is not a member of the Niger River Basin Accord primarily due to its location, and not due to the policy preferences of its government.

${ }^{20} \mathrm{http}: / / \mathrm{www} . c i d c m . u m d . e d u /$ inscr/polity/

${ }^{21}$ Further details are available at http://sedac.ciesin.columbia.edu/es/esi/

${ }^{22}$ A country is environmentally sustainable in terms of its "environmental systems" component to the extent that its vital environmental systems are maintained at healthy levels; relevant inputs include measures of air ( $\mathrm{SO} 2$ and $\mathrm{NO} 2)$ and water (phosphorus) quality. A country is environmentally sustainable in terms of its "environmental stress" component if the levels of anthropogenic stress are low enough to engender no demonstrable harm to its environmental systems; relevant inputs include fertilizer pollution, pesticide use, coal usage, and vehicular reliance. A country is environmentally sustainable in terms of its "human vulnerability" component to the extent that basic needs of people and social systems are not vulnerable to environmental disturbances; relevant inputs include death rates from respiratory and intestinal infectious disease. We note in passing that one of the (67) inputs into the ("Global Stewardship" component of the) ESI is the number of international environmental organizations in which a country participates. The main report of the ESI contains many more details of relevance; http://sedac.ciesin.columbia.edu/es/esi/ESI_01_tot.pdf .

${ }^{23}$ The core components can be further decomposed, since they in turn are based upon a set of 22 core "indicators" each of which combines two to six "variables" for a total of 67 underlying variables.

${ }^{24}$ The effect of a source country's environmental commitment is now positive and significant; we have no explanation for this result.

${ }^{25}$ The relevant part of the first stage of our IV estimates is presented in Table A4 of the appendix. It shows that the two instrumental variables (polity and ESI) are positively linked to the number of environmental treaties.

${ }^{26}$ This allows us to eliminate the two other more potentially problematic ESI components ("Social and Institutional Capacity" and "Global Stewardship").

${ }^{27} \mathrm{http} / / /$ www.cia.gov/cia/publications/factbook/appendix/appendix-c.html

${ }^{28}$ More details are available at http://web.worldbank.org/WBSITE/EXTERNAL/TOPICS/ENVIRONMENT/EXTEEI/0,,contentMDK:20502388 menuPK:1187778 pagePK:210058 piPK:210062 theSitePK:408050,00.html

${ }^{29}$ In earlier versions of this paper, we also report results of a number of other sensitivity checks.

${ }^{30}$ The data set and further information is available at http://www.bis.org/statistics/consstatsweb.htm\#

${ }^{31}$ In this case, we add controls for bilateral great-circle distance, \#landlocked countries; \#island nations, and dummies for dependencies, and common land border/ language/colonizer, or colonial history. We use the GlickRose data set.

${ }^{32}$ As instrumental variables, we use annual WDI measures of environmental degradation, including: $\mathrm{CO} 2$ emissions; organic water pollution; and particle emissions.

${ }^{33}$ Our OECD data is measured in millions of US\$, and is taken from http://fiordiliji.sourceoecd.org/vl=1792668/cl=33/nw $=1 / \mathrm{rpsv} / \sim 4145 / \mathrm{v} 45 \mathrm{n} 1 / \mathrm{s} 1 / \mathrm{p} 1$. Foreign direct investment is undertaken for many considerations that we do not consider and have not modeled here, including issues associated with: the transfer of technology; managerial considerations; taxes and subsidies; factor proportions; trade policy; product and labor market regulation; and corporate governance. Further, we make no attempt to differentiate between horizontal and vertical FDI. Perhaps most importantly, differences in the environment and environmental 
policy may well motivate FDI, since firms may well relocate production for environmental considerations. Accordingly, we view our work as a simple robustness check; further work in this area is warranted. 